\title{
Stress rise precursor to earthquakes in the Tibetan Plateau
}

\author{
Zhenhan $\mathrm{Wu}^{1^{*}}$, Qunce Chen ${ }^{2}$, Patrick J. Barosh ${ }^{3}$, Hua Peng ${ }^{2}$, Daogong $\mathrm{Hu}^{2}$ \\ ${ }^{1}$ Chinese Academy of Geological Sciences, Beijing, China; ${ }^{*}$ Corresponding Author: wuzhenhan@sohu.com \\ ${ }^{2}$ Institute of Geomechanics, Chinese Academy of Geological Sciences, Beijing, China \\ ${ }^{3}$ P.J. Barosh and Associates, Bristol, USA
}

Received 11 May 2013; revised 11 June 2013; accepted 18 June 2013

Copyright (C) 2013 Zhenhan Wu et al. This is an open access article distributed under the Creative Commons Attribution License, which permits unrestricted use, distribution, and reproduction in any medium, provided the original work is properly cited.

\section{ABSTRACT}

Earthquake prediction thus far has proven to be a very difficult task, but changes in situ stress appear to offer a viable approach for forecasting large earthquakes in Tibet and perhaps other continental regions. High stress anomalies formed along active faults before large earthquakes and disappeared soon after the earthquakes occurred in the Tibetan Plateau. Principle stress increased up to $\sim 2$ - 5 times higher than background stress to form high stress anomalies along causative faults before the Ms 8.1 West Kunlun Pass earthquake in November 2001, Ms 8.0 Wenchuan earthquake in May 2008, Ms 6.6 Nimu earthquake in October 2009, Ms 7.1 Yushu earthquake in April 2010 and the Ms 7.0 Lushan earthquake in April 2013. Stress near the epicenters rapidly increased $0.10-0.12 \mathrm{MPa}$ over 45 days, $\sim 8$ months before the Ms 6.6 Nimu earthquake occurred. The high principle stress anomalies decreased quickly to the normal stress state in -8 - 12 months after the Ms 8.1 West Kunlun Pass and the Ms 8.0 Wenchuan earthquakes. These high stress anomalies and their demise appear directly related to the immediate stress rise along a fault prior to the earthquakes and the release during the event. Thus, the stress rise appears to be a viable precursor in prediction of large continental earthquakes as in the Tibetan Plateau.

Keywords: Earthquake Prediction; High Stress Anomalies; In-Situ Stress Measurement; Large Earthquakes; Seismic Fault; Tibetan Plateau

\section{INTRODUCTION}

Large continental earthquakes are a major geologic hazard and commonly result in great disasters as recently occurred in China. The 2008 Ms 8.0 Wenchuan earthquake destroyed towns and villages along and near the seismic faults, and killed 69,227 people with 17,923 still missing [1]. The 2010 Ms 7.1 Yushu earthquake killed 2192 people with an additional 78 missing, and the 2008 Ms 6.6 Nimu earthquake resulted in significant economic loss. The Ms 7.0 Lushan earthquake occurred on April 20, 2013 killed 196 people with 21 still missing in southwestern Longmenshan Mts. Another event, the 2001 Ms 8.1 West Kunlun Pass earthquake, might have caused further devastation, but for it stroke a sparsely populated region. The Chinese government has encouraged scientists to develop effective ways for tracing and predicting large earthquakes, aiming at decreasing seismic hazards. However, earthquake prediction has thus far proven a difficult task for the world's scientists even though seismic monitoring systems are established in many countries. Here we use stress to investigate these four large earthquakes in the Tibetan Plateau in hopes of finding a viable precursor for future earthquake prediction.

Ever since Reid [2] formulated the elastic rebound theory following the 1903 San Francisco earthquake, researchers have considered the relation of stress change and earthquakes. $\mathrm{Li}$ and his colleagues advocated the prediction of earthquakes by in-situ stress measurement in the 1960s [3,4] and considerable work has been accomplished ever since on measuring stress and delineating stress regions in China [5-7]. The lithosphere stress state now has been widely probed by in-situ stress measurements $[8,9]$, but care must be used in relating these to earthquakes, because the measured stress may reflect the stress unrelated to the present tectonic movement $[6,10]$. Furthermore, although the delineation of general levels of stress can relate to general levels of seismic activity [11] this does not relate to activity along specific fault zones. Neither did estimates of deep stress arrive from epicentral distribution and focal plane solutions [12]. 
Direct measured changes in the stress fields, however, reflect the present day movement in the crust $[4,11]$ and where these changes are adjacent to active faults they may relate to the seismic activity along the fault. Even small changes in stress, such as due to reservoir filling, are enough to trigger earthquakes sometimes [3]. Investigations into the crustal stress present and possible changes have been underway for the past decade for both engineering purposes and earthquake studies in the Tibetan Plateau now have revealed several changes in measured stress.

Intensive seismicity in the Tibetan Plateau is caused by the continued northward subduction of Indian Continental Plate that has created a variety of seismically active faults [13-15], which have produced large earthquakes over the past ten years in western China (Figure 1). The Ms 8.1 West Kunlun Pass earthquake occurred on November 14, 2001 and formed a fracture zone 350 $426 \mathrm{~km}$ long on the Kusai Lake fault with a co-seismic sinistral slip of 7.6 - 8.0 m near Kusai Lake [16] and 3.5 - 4.7 m near Kunlun Pass [17]. The Ms 8.0 Wenchuan earthquake of May 12, 2008 formed a seismic rupture zone with a length of 240 - $270 \mathrm{~km}$ along the BeichuanYingxiu fault $[18,19]$ and triggered thousands of largescale landslides, huge rock falls and debris flows in the Longmenshan Mountains [1], at the eastern margin of the Tibetan Plateau. Co-seismic offsets of $4.6 \mathrm{~m}$ dip-slip and $6.1 \mathrm{~m}$ dextral-slip were measured in Yingxiu and Beichuan, respectively [1,20]. The Ms 7.1 Yushu earthquake, which occurred on April 14, 2010, formed a seismic fracture zone with a length up to $23 \mathrm{~km}$ along the Garze-Yushu fault and co-seismic sinistral slips of 1.2 $1.8 \mathrm{~m}$ happened near the epicenter northwest of Yushu. And the Ms 7.0 Lushan earthquake, which occurred on April 20, 2013, formed seismic hazards, landslides and rock falls without seismic rupture zone along the eastern marginal thrust in southwestern Longmenshan Mountains. These large earthquakes, together with the Ms 7.9 Mani earthquake that occurred on November 8, 1997, constitute the most recent activity on the faults bounding the Hohxil-Bayanhar-Garze structural block of the northern Tibetan Plateau (Figure 1). Earthquakes that

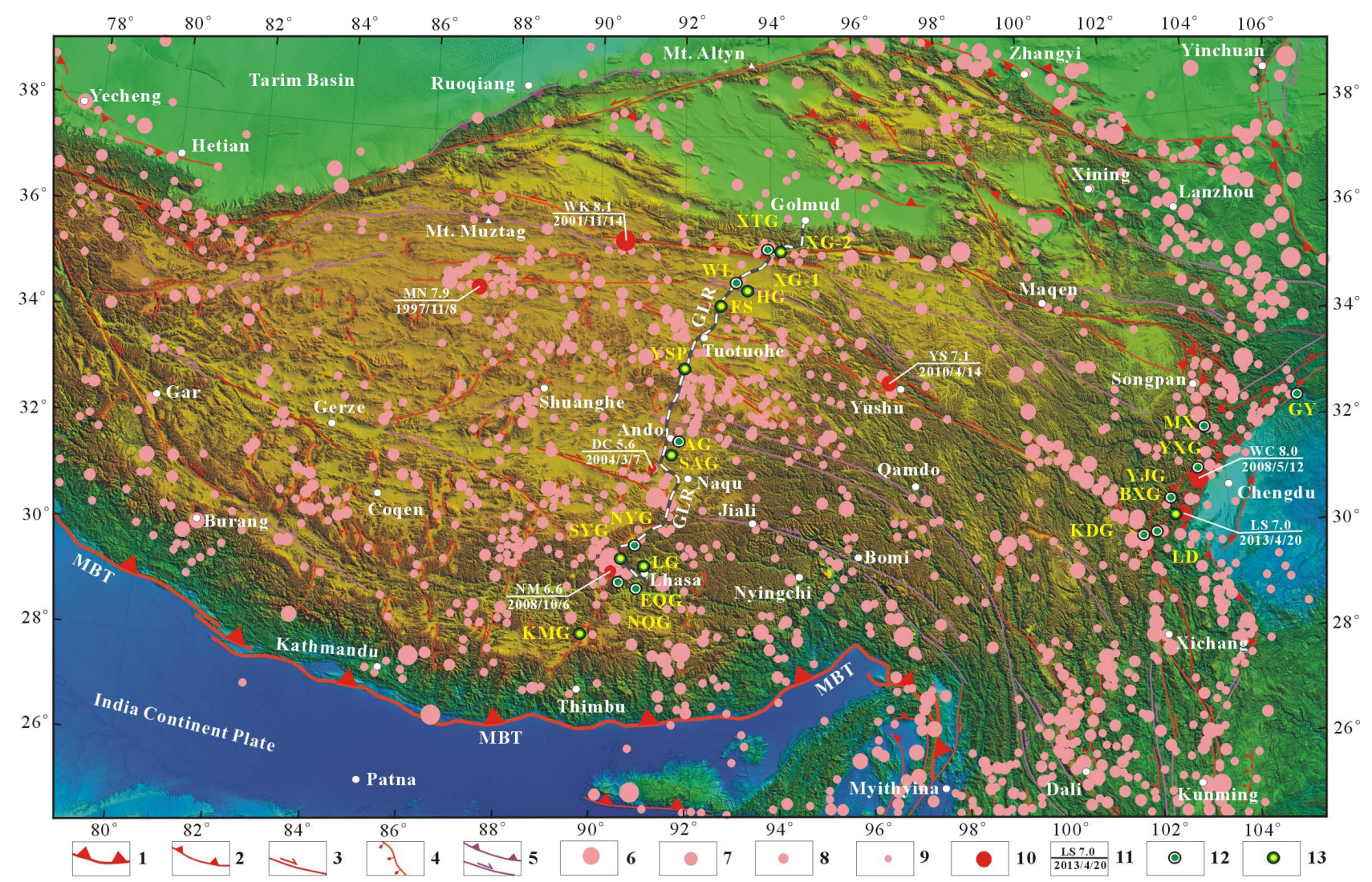

Figure 1. Tectonic map of active faults and seismicity in the Tibetan Plateau. Explanation: 1, Main Boundary Thrust (MBT); 2, Holocene thrust fault; 3, Holocene strike-slip fault; 4, Holocene normal fault; 5, Pleistocene thrust and strike-slip faults; 6 , Ms 8.0 8.5 earthquake; 7, Ms 7.0 - 7.9 earthquake; 8, Ms 6.0 - 6.9 earthquake; 9, Ms 5.0 - 5.9 earthquake; 10, epicenter of earthquake in recent years; 11, location, magnitude and date of earthquake; 12, hydraufracturing stress measurement; 13, piezomagnetic stress measurement. The GLR refers to the Golmud-Lhasa Railway. The MN, WK, DC, YS, NM, WC and LS refer to the Mani, West of Kunlun Pass, Dong Co, Yushu, Nimu, Wenchuan and Lushan earthquakes, respectively. The XTG, XG-1, XG-2, WL, SYG, KMG, KDG, YJG, YXG, MX, BXG and others marked by yellow refer to the sites for stress measurement. 
occurred in the central Tibetan Plateau, such as the Ms 5.6 Dongco earthquake on March 7, 2004 and the Ms 6.6 Nimu earthquake on October 6, 2008, resulted from activity along the boundary normal faults of the YadongYangbajain-Gulu graben system.

\section{STRESS CHANGES BEFORE AND AFTER LARGE EARTHQUAKES}

Stress measurements by both the hydraulic fracturing and piezomagnetic methods have been taken in boreholes about the Tibetan Plateau since 2001 to provide data to characterize the stress field in which the large earthquakes occur and for engineering work. The great majority of the sites are in granite and gabbro. Hydraulic fracturing stress measurements were made in Xidatan granite (XTG), Wudaoliang limestone (WL), Ando gabbro (AG), Northeastern Yangbajain granite (NYG), Northwestern Quxi granite (NQG), Eastern Quxi granite (EQG) [21] along Golmud-Lhasa Railway across the Tibetan Plateau (Table 1). Hydraulic fracturing stress measurements in the Yaoji granite (YJG) [22], Yingxiu granite, Kangding granite (KDG) [19], Maoxian (MX) and Guanyuan (GY) [23] were conducted before and after the Ms 8.0 Wenchuan earthquake in central Longmenshan Mountains at the eastern margin of the Tibetan Plateau (Figure 1).

Piezomagnetic stress measurements were undertaken in the Xidatan granite (XG-1) and Xidatan gabbro (XG-2) [24], Hohxil granite (HG), Fenghuoshan siltstone (FS), Yanshiping sandstone (YSP), South Ando granite (SAG) [7], Southeastern Yangbajain granite (SYG), Lhasa granite (LG) and Kangma granite (KG) [25] (Figure 1). These contributed valuable data (Table 2) for construction of the Golmud-Lhasa railway and revealed an obvious stress change before and after the Ms 8.1 West Kunlun Pass earthquake [24]. And Piezomagnetic stress measurement in the Baoxing Granite (BXG) and Hydraulic fracturing stress measurement in the Luding (LD) were conducted before the Ms 7.0 Lushan earthquake in the southwestern Longmenshan Mountains.

Stress is measured at different depths in order to formulate the stress increase due to the additional rock mass with depth. Stress was measured by hydraulic fracturing on December 6, 2005 in a $301 \mathrm{~m}$ deep borehole in the Northeastern Yangbajain granite (NYG), east of Yangbajain graben. The maximum principle stress $\left(\mathrm{S}_{\mathrm{H}}\right)$ and minimal principle stress $\left(\mathrm{S}_{\mathrm{h}}\right)$ at NYG increase from 4.62 $\mathrm{MPa}$ and $3.82 \mathrm{MPa}$, respectively, at a depth $60 \mathrm{~m}$ to 11.34 $\mathrm{MPa}$, and 10.20 $\mathrm{MPa}$ at $286 \mathrm{~m}(\mathrm{MPa}=145.0377$ psi) (Table 1). The stress change with depth is found to be $\mathrm{S}_{\mathrm{H}}=2.56+0.0340 \mathrm{D}$ and $\mathrm{S}_{\mathrm{h}}=1.34+0.0325 \mathrm{D}$ with $\mathrm{D}$ referring to depth in meters. The NYG is located in central Lhasa block, $\sim 9 \mathrm{~km}$ away from the active fault along the western boundary of the Yangbajain graben, and seismicity surrounding NYG is very weak (Figure 1).
The stress recorded in NYG is therefore taken as representative for relatively stable areas in the Tibetan Plateau and is used as the background stress in analyzing stress anomalies (Figures 2 and 3).

Several other sites, AG, WL, LG and GY, also are located in relative stable areas away from seismic faults and seismic zones (Figure 1), and are characterized by relatively lower principle stress similar to NYG (Figures 2 and 3). Measurements along the Golmud-Lhasa railway found $\mathrm{S}_{\mathrm{H}}$ and $\mathrm{S}_{\mathrm{h}}$ in $\mathrm{AG}$ changed from $4.50 \mathrm{MPa}$ and $3.82 \mathrm{MPa}$, respectively, at a depth of $50 \mathrm{~m}$ to $5.56 \mathrm{MPa}$ and $5.00 \mathrm{MPa}$, respectively, at $135 \mathrm{~m}$; the $\mathrm{S}_{\mathrm{H}}$ and $\mathrm{S}_{\mathrm{h}}$ in WL changed from 3.33 $\mathrm{MPa}$ and 2.30 $\mathrm{MPa}$, respectively, at a depth of $28 \mathrm{~m}$ to $7.78 \mathrm{MPa}$ and $5.10 \mathrm{MPa}$ at $116 \mathrm{~m}$; and the $\mathrm{S}_{\mathrm{H}}$ and $\mathrm{S}_{\mathrm{h}}$ in LG was 4.6 MPa and 2.6 MPa, respectively, at a depth of $18 \mathrm{~m}$ (Figures 2 and 3). At the northwest margin of the South China Block, $\mathrm{S}_{\mathrm{H}}$ increased from $6 \mathrm{MPa}$ at $100 \mathrm{~m}$ depth to $20 \mathrm{MPa}$ at $347 \mathrm{~m}$ and $\mathrm{S}_{\mathrm{h}}$ increased from $5 \mathrm{MPa}$ at a depth of $100 \mathrm{~m}$ to $10 \mathrm{MPa}$ at $347 \mathrm{~m}$ in Guanyuan (GY), northeast of Chengdu (Figures 2 and 3 ).

In contrast, the maximum principle stress $\mathrm{S}_{\mathrm{H}}$ found along the active faults is abnormally high; always 2 - 5 times higher than in NYG; and the minimal principle stress $S_{h}$ along the fault zones also increased before large earthquakes in the northern, eastern and central Tibetan Plateau. These formed high stress zones in $\mathrm{S}_{\mathrm{H}}$-D (Figure 2) and $S_{h}-D$ diagrams (Figure 3 ).

\subsection{West Kunlun Pass Earthquake (WK)}

The principle stress $\mathrm{S}_{\mathrm{H}}$ and $\mathrm{S}_{\mathrm{h}}$ increased to $12.9 \mathrm{MPa}$ and $12.1 \mathrm{MPa}$, respectively, at XG-1 at a depth of $18 \mathrm{~m}$ and 6.8 $\mathrm{MPa}$ and 4.4 MPa at XG-2 at a depth of $14 \mathrm{~m}$ in August 2001 (Table 2), 3 months before the Ms 8.1 West Kunlun Pass earthquake [24]. The $\mathrm{S}_{\mathrm{H}}$ and $\mathrm{S}_{\mathrm{h}}$ then decreased to 3.5 $\mathrm{MPa}$ and 3.2 $\mathrm{MPa}$, respectively at XG-1 at a depth of $18 \mathrm{~m}$ and $2.2 \mathrm{MPa}$ and $1.2 \mathrm{MPa}$, respectively, in XG-2 at $14 \mathrm{~m}$ depth in July 2002 (Table 2), 8 months after the Ms 8.1 West Kunlun Pass earthquake [24]. The principle stress $S_{H}$ and $S_{h}$ at XTG decreased to 2.32 - $7.88 \mathrm{MPa}$ and 2.20 - 5.70 MPa, respectively, between depths of 44 and $152 \mathrm{~m}$ and $11.07-10.74 \mathrm{MPa}$ and 7.0 - 6.5 MPa, at depths of 168 - $176 \mathrm{~m}$ (Figures 2 and 3).

\subsection{Wenchuan Earthquake (WC)}

The Ms 8.0 Wenchuan earthquake on May 12, 2008 resulted from an eastward thrust of the Songpan-Garze terrain over the South China Block [18,20]. The maximum principle stress $\left(\mathrm{S}_{\mathrm{H}}\right)$ in the eastward thrust sheet was measured at 14.44-25.53 MPa from depths of 180.3 $\mathrm{m}$ to $280.5 \mathrm{~m}$ at YJG in 1999, 9 years before the earthquake. This was in contrast with general values of 7.8 
Table 1. Stress measured by hydraulic fracturing in the Tibetan Plateau.

\begin{tabular}{|c|c|c|c|c|c|c|c|c|c|c|}
\hline \multirow{2}{*}{$\begin{array}{l}\text { Site and rock/date } \\
\text { measured }\end{array}$} & \multirow{2}{*}{$\begin{array}{l}\text { Depth } \\
(\mathrm{m})\end{array}$} & \multicolumn{5}{|c|}{ Hydraulic fracturing parameters (MPa) } & \multicolumn{3}{|c|}{ Stress (MPa) } & \multirow{2}{*}{$\begin{array}{l}\text { Orientation } \\
\text { of } \mathrm{S}_{\mathrm{H}}\end{array}$} \\
\hline & & $\mathrm{Pb}$ & Pr & Ps & Po & $\mathrm{T}$ & $\mathrm{S}_{\mathrm{H}}$ & $\mathrm{S}_{\mathrm{h}}$ & $\mathrm{S}_{\mathrm{v}}$ & \\
\hline \multirow{7}{*}{$\begin{array}{c}\text { Xidatan granite } \\
\text { (XTG)*/August, } 2005\end{array}$} & 44.0 & 5.92 & 4.25 & 2.20 & 0.03 & 1.67 & 2.32 & 2.20 & 1.15 & $\mathrm{~N} 21^{\circ} \mathrm{E}$ \\
\hline & 64.0 & 7.66 & 4.03 & 2.30 & 0.23 & 3.63 & 2.64 & 2.30 & 1.67 & \\
\hline & 84.0 & 8.92 & 6.40 & 3.50 & 0.44 & 2.52 & 3.66 & 3.50 & 2.20 & $\mathrm{~N} 29^{\circ} \mathrm{E}$ \\
\hline & 126.0 & 7.40 & 7.03 & 5.20 & 0.86 & 0.37 & 7.71 & 5.20 & 3.29 & \\
\hline & 152.0 & 10.29 & 8.10 & 5.70 & 1.12 & 2.18 & 7.88 & 5.70 & 3.98 & $\mathrm{~N} 43^{\circ} \mathrm{E}$ \\
\hline & 168.0 & 9.36 & 8.66 & 7.00 & 1.27 & 0.70 & 11.07 & 7.00 & 4.38 & $\mathrm{~N} 34^{\circ} \mathrm{E}$ \\
\hline & 176.0 & 8.70 & 7.40 & 6.50 & 1.36 & 1.30 & 10.74 & 6.50 & 4.59 & $\mathrm{~N} 42^{\circ} \mathrm{E}$ \\
\hline \multirow{4}{*}{$\begin{array}{l}\text { Wudaoliang limestone } \\
\text { (WL)*/August, } 2006\end{array}$} & 50.0 & 7.97 & 6.24 & 3.82 & 0.50 & 1.73 & 4.72 & 3.82 & 1.50 & \\
\hline & 65.0 & 8.03 & 6.30 & 3.82 & 0.66 & 1.73 & 4.50 & 3.82 & 1.98 & $\mathrm{~N} 10^{\circ} \mathrm{W}$ \\
\hline & 93.0 & 8.67 & 7.01 & 4.82 & 0.93 & 1.66 & 6.52 & 4.82 & 2.79 & \\
\hline & 135.0 & 10.01 & 8.08 & 5.00 & 1.36 & 1.93 & 5.56 & 5.00 & 4.07 & \\
\hline \multirow{5}{*}{$\begin{array}{c}\text { Ando gabbro } \\
(\mathrm{AG})^{* *} / \text { October, } 2005\end{array}$} & 28.0 & 4.74 & 3.40 & 2.30 & 0.16 & 1.33 & 3.33 & 2.30 & 0.79 & $\mathrm{~N} 11^{\circ} \mathrm{W}$ \\
\hline & 55.0 & 6.13 & 3.22 & 2.20 & 0.43 & 2.90 & 2.94 & 2.20 & 1.55 & \\
\hline & 75.0 & 7.13 & 5.12 & 3.60 & 0.63 & 2.01 & 5.05 & 3.60 & 2.11 & $\mathrm{~N} 24^{\circ} \mathrm{W}$ \\
\hline & 91.0 & 5.92 & 5.62 & 4.00 & 0.79 & 0.30 & 5.58 & 4.00 & 2.56 & \\
\hline & 116.0 & 8.23 & 6.48 & 5.10 & 1.04 & 1.75 & 7.78 & 5.10 & 3.26 & $\mathrm{~N} 13^{\circ} \mathrm{W}$ \\
\hline \multirow{8}{*}{$\begin{array}{l}\text { Northeastern Yangbajain granite } \\
(\mathrm{NYG})^{* * *} / \text { December, } 2005\end{array}$} & 60.0 & 7.97 & 6.24 & 3.82 & 0.60 & 1.73 & 4.62 & 3.82 & 1.81 & \\
\hline & 85.0 & 8.13 & 6.30 & 3.82 & 0.86 & 1.83 & 4.30 & 3.82 & 2.57 & $\mathrm{~N} 55^{\circ} \mathrm{E}$ \\
\hline & 113.0 & 8.87 & 7.31 & 4.82 & 1.14 & 1.56 & 6.02 & 4.82 & 3.41 & \\
\hline & 139.0 & 10.25 & 9.10 & 6.14 & 1.40 & 1.15 & 7.92 & 6.14 & 4.19 & \\
\hline & 222.0 & 14.40 & 12.30 & 8.10 & 2.23 & 2.10 & 9.77 & 8.10 & 6.68 & \\
\hline & 243.0 & 16.60 & 14.10 & 9.20 & 2.44 & 2.50 & 11.06 & 9.20 & 7.31 & \\
\hline & 261.0 & 18.30 & 16.90 & 10.8 & 2.62 & 1.40 & 12.88 & 10.80 & 7.85 & $\mathrm{~N} 65^{\circ} \mathrm{E}$ \\
\hline & 286.0 & 18.73 & 16.40 & 10.2 & 2.86 & 2.33 & 11.34 & 10.20 & 8.59 & $\mathrm{~N} 53^{\circ} \mathrm{E}$ \\
\hline \multirow{4}{*}{$\begin{array}{l}\text { Northwestern Quxi granite } \\
\text { (NQG)*/July, } 2007\end{array}$} & 73.8 & 16.84 & 13.34 & 8.54 & 0.54 & 3.50 & 11.73 & 8.54 & 1.96 & \\
\hline & 115.8 & 23.58 & 11.76 & 9.03 & 0.96 & 11.82 & 14.36 & 9.03 & 3.07 & $\mathrm{~N} 46.5^{\circ} \mathrm{W}$ \\
\hline & 122.3 & 16.18 & 10.72 & 8.63 & 1.03 & 5.46 & 14.15 & 8.63 & 3.24 & $\mathrm{~N} 39.6^{\circ} \mathrm{W}$ \\
\hline & 134.8 & 18.52 & 9.72 & 7.65 & 1.15 & 8.80 & 12.07 & 7.65 & 3.57 & \\
\hline \multirow{5}{*}{$\begin{array}{c}\text { Eastern Quxi granite } \\
\text { (EQG) }{ }^{* *} / \text { After Cao et al., } 2003 \\
\text { [21] }\end{array}$} & 133.0 & 25.43 & 6.84 & 5.75 & 0.90 & 18.60 & 9.51 & 5.75 & 3.60 & \\
\hline & 170.0 & - & 6.12 & 6.80 & 1.27 & - & 13.01 & 6.80 & 4.60 & \\
\hline & 241.0 & 24.10 & 12.60 & 10.90 & 1.98 & 11.50 & 18.12 & 10.90 & 6.50 & $\mathrm{~N} 3.0^{\circ} \mathrm{E}$ \\
\hline & 283.0 & 16.43 & 11.00 & 10.31 & 2.40 & 5.43 & 17.53 & 10.31 & 7.60 & \\
\hline & 296.0 & 24.80 & 11.12 & 9.08 & 2.53 & 13.60 & 13.59 & 9.08 & 8.00 & \\
\hline \multirow{7}{*}{$\begin{array}{l}\text { Yaoji granite (YJG)/after } \\
\text { Mao et al., } 1999 \text { [22] }\end{array}$} & 180.3 & 9.04 & 8.34 & 8.28 & 1.08 & 0.7 & 15.42 & 8.28 & 4.77 & \\
\hline & 187.6 & 12.72 & 8.95 & 8.19 & 1.15 & 3.77 & 14.44 & 8.19 & 4.96 & $\mathrm{~N} 57^{\circ} \mathrm{E}$ \\
\hline & 224.4 & 14.23 & 12.46 & 11.61 & 1.51 & 1.77 & 20.86 & 11.61 & 5.49 & $\mathrm{~N} 63^{\circ} \mathrm{E}$ \\
\hline & 233.3 & 16.69 & 13.66 & 11.11 & 1.60 & 3.03 & 18.07 & 11.11 & 6.18 & $\mathrm{~N} 1{ }^{\circ} \mathrm{W}$ \\
\hline & 250.3 & 12.29 & 10.89 & 10.80 & 1.77 & 1.40 & 19.74 & 10.80 & 6.63 & $\mathrm{~N} 55^{\circ} \mathrm{E}$ \\
\hline & 259.1 & 13.69 & 11.81 & 11.68 & 1.85 & 1.88 & 21.38 & 11.68 & 6.86 & \\
\hline & 280.5 & 15.60 & 13.00 & 13.53 & 2.06 & 2.60 & 25.53 & 13.53 & 7.42 & \\
\hline
\end{tabular}




\begin{tabular}{|c|c|c|c|c|c|c|c|c|c|c|}
\hline \multirow{5}{*}{$\begin{array}{l}\text { Yingxiu granite (YXG)/after } \\
\text { Wu et al., } 2009 \text { [19] }\end{array}$} & 90.0 & 4.30 & 3.50 & 2.60 & 0.82 & 0.80 & 3.48 & 2.60 & 2.39 & \multirow{5}{*}{$\mathrm{N} 56^{\circ} \mathrm{W}$} \\
\hline & 128.0 & 13.62 & 12.78 & 7.44 & 1.20 & 0.84 & 8.34 & 7.44 & 3.39 & \\
\hline & 142.0 & 9.95 & 8.70 & 5.95 & 1.34 & 1.25 & 7.81 & 5.95 & 3.76 & \\
\hline & 171.0 & 18.21 & 18.18 & 11.81 & 1.63 & 0.03 & 15.62 & 11.81 & 4.53 & \\
\hline & 185.0 & 12.73 & 10.17 & 8.35 & 1.77 & 2.56 & 13.11 & 8.35 & 4.90 & \\
\hline \multirow{7}{*}{$\begin{array}{l}\text { Kangding granite (KDG)/after } \\
\text { Wu et al., } 2009 \text { [19] }\end{array}$} & 55.0 & 4.47 & 3.27 & 1.70 & 0.31 & 1.20 & 1.74 & 1.70 & 1.46 & $\mathrm{~N} 5^{\circ} \mathrm{E}$ \\
\hline & 81.0 & 4.66 & 3.91 & 2.44 & 0.57 & 0.75 & 2.84 & 2.44 & 2.15 & \multirow[t]{6}{*}{$\mathrm{N} 81^{\circ} \mathrm{E}$} \\
\hline & 94.0 & 4.10 & 3.61 & 2.52 & 0.70 & 0.49 & 3.25 & 2.52 & 2.49 & \\
\hline & 117.0 & 5.03 & 3.93 & 2.31 & 0.93 & 1.10 & 2.46 & 2.42 & 3.10 & \\
\hline & 136.0 & 9.81 & 6.12 & 3.55 & 1.12 & 3.69 & 3.67 & 3.55 & 3.60 & \\
\hline & 172.0 & 17.32 & 11.47 & 5.92 & 1.48 & 5.85 & 6.41 & 6.12 & 4.56 & \\
\hline & 186.0 & 10.91 & 6.89 & 4.94 & 1.62 & 4.02 & 6.31 & 4.94 & 4.93 & \\
\hline Luding (LD) & 150.0 & & & & & & 16.00 & 10.00 & 4.00 & $\mathrm{~N} 60^{\circ} \mathrm{W}$ \\
\hline Maoxian (MX) & 229.0 & & & & & & 14.00 & 8.00 & 6.00 & $\mathrm{~N} 55^{\circ} \mathrm{W}$ \\
\hline \multirow{3}{*}{$\begin{array}{l}\text { Guanyuan (GY)/after } \\
\text { An et al., } 2004 \text { [23] }\end{array}$} & 100.0 & & & & & & 6.00 & 5.00 & 2.65 & $\mathrm{~N} 30^{\circ} \mathrm{W}$ \\
\hline & 200.0 & & & & & & 7.50 & 7.00 & 5.30 & \multirow[t]{2}{*}{$\mathrm{N} 35^{\circ} \mathrm{W}$} \\
\hline & 347.0 & & & & & & 20.00 & 10.00 & 9.20 & \\
\hline
\end{tabular}

Explanation: $\mathrm{P}_{\mathrm{b}}$, break down pressure; $\mathrm{P}_{\mathrm{r}}$, re-opening pressure; $\mathrm{P}_{\mathrm{s}}$, shut-in pressure; $\mathrm{P}_{\mathrm{o}}$ : pore pressure; T, tensor strength; $S_{\mathrm{H}}$, horizontal maximum principle stress; $S_{\mathrm{h}}$, horizontal minimal principle stress; $\mathrm{S}_{\mathrm{v}}$, vertical stress caused by overloading rocks with density $2.63\left(\mathrm{~g} / \mathrm{cm}^{3}\right)^{*}, 2.70\left(\mathrm{~g} / \mathrm{cm}^{3}\right)^{* *}$ or $3.02\left(\mathrm{~g} / \mathrm{cm}^{3}\right)^{* * *}$. Stress of LD, MX and GY came from An et al., 2004 [23]. Sites of measured stress are marked by yellow in Figure 1.

MPa at depths of $170 \mathrm{~m}$ found to the northwest [6]. The stress then had decreased to 3.48 - $8.34 \mathrm{MPa}$ between depths of $90 \mathrm{~m}$ to $142 \mathrm{~m}$ at YXG and $1.74-6.41 \mathrm{MPa}$ from depths of $55 \mathrm{~m}$ to $186 \mathrm{~m}$ at KDG in 2009 (Figure 2), one year after the Wenchuan earthquake. The minimal principle stress $\left(\mathrm{S}_{\mathrm{h}}\right)$ also changed from high anomaly at YJG before the Wenchuan earthquake to normal in YXG at depths of 90 - $142 \mathrm{~m}$ and in KDG at depths of 55 - 186 $\mathrm{m}$ after the earthquake (Figure 3 ). The principle stress still remained at higher values at greater depths. The $\mathrm{S}_{\mathrm{H}}$ and $\mathrm{S}_{\mathrm{h}}$ was 13.11 - $15.62 \mathrm{MPa}$ and 11.81 - 8.35 $\mathrm{MPa}$, respectively, at depths of 171 - $185 \mathrm{~m}$ in Yingxiu (YXG) along the seismic Beichuan-Yingxiu fault one year after the Wenchuan earthquake (Tables 1 and 2). High principle stress also occurred in Maoxian (MX) along the seismic Beichuan-Yingxiu fault, and the $\mathrm{S}_{\mathrm{H}}$ and $\mathrm{S}_{\mathrm{h}}$ were $14 \mathrm{MPa}$ and $8 \mathrm{MPa}$, respectively, in MX at a depth of $229 \mathrm{~m}$ (Table 1). However, the stress had remained low with $\mathrm{S}_{\mathrm{H}}, 6-7.5 \mathrm{MPa}$, and $\mathrm{S}_{\mathrm{h}}, 5.0-7.0 \mathrm{MPa}$ in $\mathrm{GY}$ at depths of $100-200 \mathrm{~m}$ in the stable South China Block [23], 4 years before the Wenchuan earthquake.

\subsection{Dongco Earthquake (DC)}

The Ms 5.6 Dongco earthquake, which was due to normal fault offset in the Yadong-Yangbajain-Gulu graben system, was preceded by a high stress anomaly in the South Ando granite (SAG) (Figures 2 and 3). Principle stress $\mathrm{S}_{\mathrm{H}}$ and $\mathrm{S}_{\mathrm{h}}$ reached 8.1 $\mathrm{MPa}$ and 4.8 $\mathrm{MPa}$, respectively, in SAG at a depth of $14 \mathrm{~m}$ in July 2003; this is more than 2 times higher than background stress (Figures 2 and 3), and $\sim 8$ months later the Dongco earthquake occurred southwest of SAG in the Ando-Dongco graben on March 7, 2004 (Figure 1).

\subsection{Nimu Earthquake (NM)}

A high stress anomaly also was found adjacent to the Yadong-Yangbajain graben system before the Ms 6.6 Nimu earthquake occurred on October 6, 2008. Principle stress $\mathrm{S}_{\mathrm{H}}$ and $\mathrm{S}_{\mathrm{h}}$ was as high as 5.7 - 10.4 MPa and 4.6 8.4 MPa, respectively, in SYG at a depth of 12 - $13 \mathrm{~m}$ in October-November 2001, and reached 11.73-14.36 MPa and 7.65 - 9.03 MPa at a depth of 73.8 - 134.8m in NQG in July 2007 (Figures 2 and 3), one year before the Nimu earthquake. Stress in NQG at a depth of 31 - $35 \mathrm{~m}$ increased quickly $\sim 8$ months before the earthquake; $\mathrm{S}_{1}$, oriented $\mathrm{N} 40^{\circ} \mathrm{W}$, changed from $7.855 \mathrm{MPa}$ to $7.958 \mathrm{MPa}$; $\mathrm{S}_{2}$, oriented $\mathrm{S} 80^{\circ} \mathrm{W}$ changed from $9.627 \mathrm{MPa}$ to 9.751 $\mathrm{MPa}$; and $\mathrm{S}_{3}$, oriented $\mathrm{N} 20^{\circ} \mathrm{E}$, changed from 7.312 $\mathrm{MPa}$ to 7.426 $\mathrm{MPa}$. Thus $\mathrm{S}_{1}, \mathrm{~S}_{2}$ and $\mathrm{S}_{3}$ increased $0.103 \mathrm{MPa}$, $0.124 \mathrm{MPa}$ and $0.114 \mathrm{MPa}$, respectively, in 45 days from January 13 to February 26, 2008 (Figure 4). However, the principle stress in relatively stable areas away from Yadong-Yangbajain graben system remained lower (Figure 2) even though the measurement sites are not located too far from the epicenter of the Nimu earthquake. The $\mathrm{S}_{\mathrm{H}}$ and $\mathrm{S}_{\mathrm{h}}$ in NYG ranged from 4.62 $\mathrm{MPa}$ and 3.82 $\mathrm{MPa}$, respectively, at $60 \mathrm{~m}$ depth to $11.34 \mathrm{MPa}$ and $10.20 \mathrm{MPa}$ at a depth of $286 \mathrm{~m}$ in December 2005, and $\mathrm{S}_{\mathrm{H}}$ and $\mathrm{S}_{\mathrm{h}}$ in 


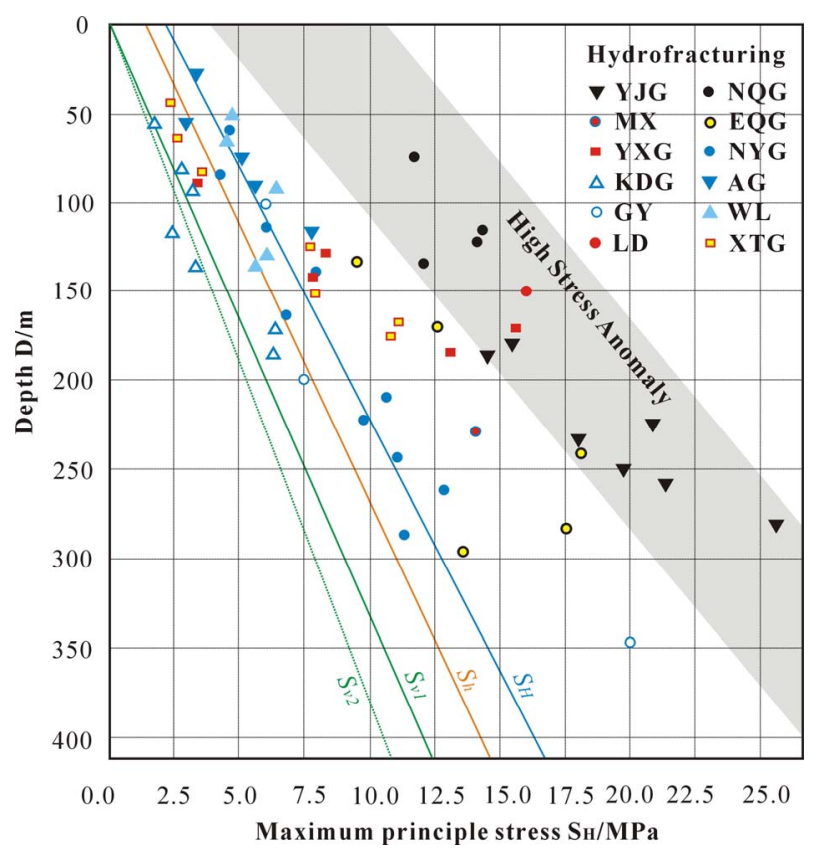

Figure 2. Vertical change of maximum principle stress in the Tibetan Plateau. Explanation: $\mathrm{S}_{\mathrm{H}}$, maximum principle stress of Yangbajain granite at NYG; $S_{h}$, minimal principle stress of Yangbajain granite at NYG; $\mathrm{S}_{\mathrm{v} 1}$ and $\mathrm{S}_{\mathrm{v} 2}$, vertical stress caused by overlying rocks with average densities of $3.02 \mathrm{~g} / \mathrm{cm}^{3}$ and 2.7 $\mathrm{g} / \mathrm{cm}^{3}$ respectively. The shaded area refers to high stress zone for large earthquakes.

EQG ranged between 9.51 - 18.12 MPa and 5.75 - 10.90 MPa, respectively, at depths of 133 - $283 \mathrm{~m}$ in 2003 (Table 1).

\subsection{Yushu Earthquake (YS)}

The Ms 7.1 Yushu earthquake followed high stress in the Hohxil granite (HG) and Fenghuoshan siltstone (FS). Principle stress $S_{\mathrm{H}}$ and $\mathrm{S}_{\mathrm{h}}$ were $6.8 \mathrm{MPa}$ and $3.2 \mathrm{MPa}$, respectively, in HG at a depth of $20 \mathrm{~m}$ in May 2002; 4.6 $5.5 \mathrm{MPa}$ and 2.8 - 2.9 MPa, respectively, in FS at depths of 12 - $16 \mathrm{~m}$ in August 2002; being 1.8 - 2.7 times higher than background stress (Figure 5). The high stress in HG and FS formed along the Wudaoliang and Fenghuoshan sinistral-slip faults, which are en echelon or branch faults of Garze-Yushu fault which broke during the earthquake. The Yushu earthquake occurred on April 14, 2010 along southern boundary faults of Hohxil-Bayanhar-Garze block (Figure 1).

\subsection{Lushan Earthquake (LS)}

The Ms 7.0 Lushan earthquake occurred along the Eastern Marginal Thrust, southwestern Longmenshan Mts. on April 20, 2013, 5 years after the Ms 8.0 Wenchuan earthquake along the Beichuan-Yingxiu fault, central Longmenshan Mts. High stress anomalies were found in the Luding (LD) (Figures $\mathbf{2}$ and $\mathbf{3}$ ) and Baoxing

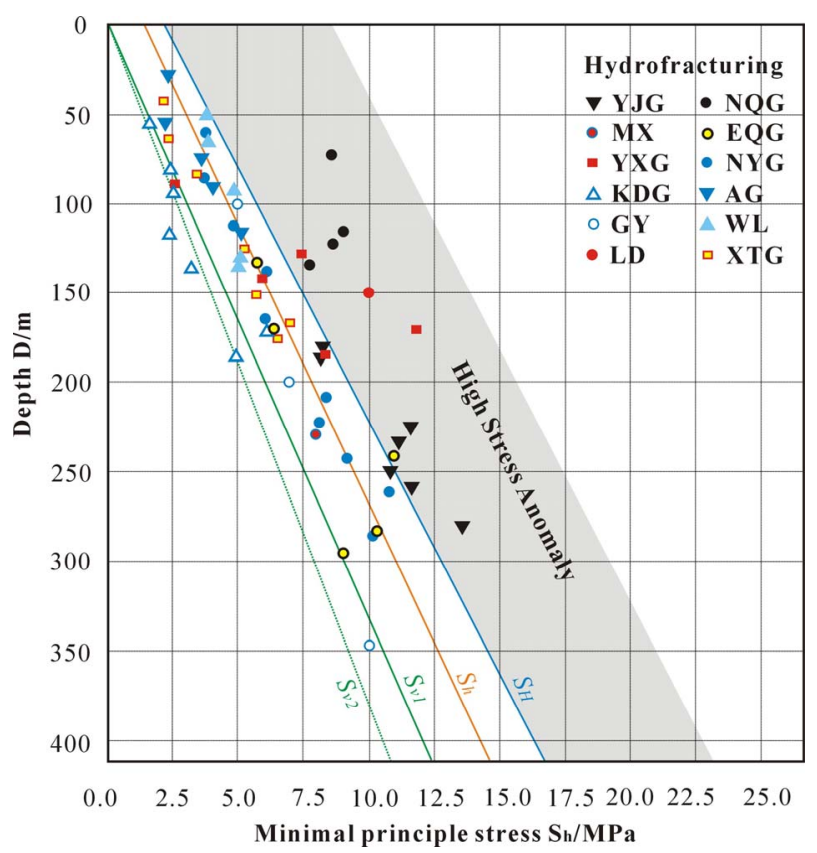

Figure 3. Vertical change of minimal principle stress in the Tibetan Plateau. Explanation: same as Figure 2.

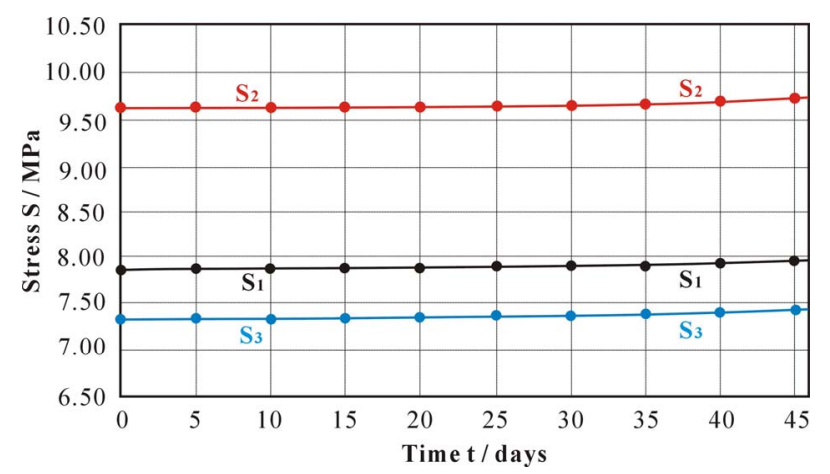

Figure 4. Diagram of stress changes in Northwestern Quxi granite. Explanation: $S_{1}, S_{2}$ and $S_{3}$ represents piezomagnetic stress measured in bore hole at depth of $31-35 \mathrm{~m}$ at orientations of $\mathrm{N} 40^{\circ} \mathrm{W}, \mathrm{S} 80^{\circ} \mathrm{W}$ and $\mathrm{N} 20^{\circ}$, respectively, from January 13 to February 26, 2008.

granite (BXG) (Figure 5) before the Ms 7.0 Lushan earthquake. The $S_{H}$ and $S_{h}$ were $16 \mathrm{MPa}$ and $10 \mathrm{MPa}$, respectively, in LD at $150 \mathrm{~m}$ depth (An et al., 2004), and the principle stress $\mathrm{S}_{\mathrm{H}}$ and $\mathrm{S}_{\mathrm{h}}$ increased to $9.8 \mathrm{MPa}$ and 7.9 $\mathrm{MPa}$, respectively, in Baoxing Granite (BXG) at depth of 18 - $22 \mathrm{~m}$ in September 2009, 3.5 years before the Ms 7.0 Lushan earthquake (Table 2).

\section{CONCLUSIONS AND DISCUSSION}

The principle stress along the seismically active faults generally rose to $\sim 2-5$ times higher than background stress before large earthquakes occurred in the Tibetan Plateau and high stress anomalies near seismic faults were precursors of large earthquakes (Figures 2, 3 and 
Table 2. Stress measured by piezomagnetic method in Tibetan Plateau.

\begin{tabular}{|c|c|c|c|c|c|c|}
\hline Site and rock & Date & Depth (m) & $\mathrm{S}_{\mathrm{H}}(\mathrm{Mpa})$ & $\mathrm{S}_{\mathrm{h}}(\mathrm{Mpa})$ & $\mathrm{S}_{\mathrm{H}}$ orientation & Reference \\
\hline Xidatan granite (XG-1) & August 2001 & 18 & 12.9 & 12.1 & $\mathrm{~N} 45^{\circ} \mathrm{E}$ & {$[24]$} \\
\hline Xidatan granite (XG-1) & July 2002 & 18 & 3.5 & 3.2 & $\mathrm{~N} 66^{\circ} \mathrm{E}$ & {$[24]$} \\
\hline Xidatan gabbro (XG-2) & August 2001 & 14 & 6.8 & 4.4 & $\mathrm{~N} 58^{\circ} \mathrm{E}$ & {$[24]$} \\
\hline Xidatan gabbro (XG-2) & July 2002 & 14 & 2.2 & 1.2 & $\mathrm{~N} 5^{\circ} \mathrm{W}$ & {$[24]$} \\
\hline Hohxil granite (HG) & May 2002 & 20 & 6.8 & 3.2 & $\mathrm{~N} 26^{\circ} \mathrm{E}$ & [7] \\
\hline \multirow{2}{*}{ Fenghuoshan siltstone (FS) } & August 2002 & 16 & 5.5 & 2.9 & $\mathrm{~N} 84^{\circ} \mathrm{E}$ & [7] \\
\hline & August 2002 & 12 & 4.6 & 2.8 & $\mathrm{~N} 61^{\circ} \mathrm{E}$ & {$[7]$} \\
\hline Yangshiping sandstone (YSP) & June 2003 & 13 & 5.6 & 4.4 & $\mathrm{~N} 47^{\circ} \mathrm{E}$ & {$[7]$} \\
\hline South Ando granite (SAG) & July 2003 & 14 & 8.1 & 4.8 & $\mathrm{~N} 64^{\circ} \mathrm{W}$ & {$[7]$} \\
\hline \multirow{3}{*}{ Southeastern Yangbajain granite (SYG) } & October 2001 & 13 & 10.4 & 8.4 & $\mathrm{~N} 70^{\circ} \mathrm{E}$ & {$[25]$} \\
\hline & October 2001 & 12 & 5.7 & 2.7 & $\mathrm{~N} 81^{\circ} \mathrm{E}$ & {$[25]$} \\
\hline & November 2001 & 12 & 6.6 & 4.6 & $\mathrm{~N} 45^{\circ} \mathrm{E}$ & {$[25]$} \\
\hline Lhasa granite (LG) & October 2003 & 18 & 4.0 & 2.6 & $\mathrm{~N} 38^{\circ} \mathrm{W}$ & {$[25]$} \\
\hline Kangma granite (KMG) & September 2003 & 13 & 5.2 & 4.4 & $\mathrm{~N} 49^{\circ} \mathrm{W}$ & {$[25]$} \\
\hline Baoxing granite (BXG) & September 2009 & $18-22$ & 9.8 & 7.9 & $\mathrm{~N} 51^{\circ} \mathrm{W}$ & [19] \\
\hline Yingxiu Granite (YXG) & September 2009 & 20 & 4.3 & 2.7 & $\mathrm{~N} 19^{\circ} \mathrm{E}$ & [19] \\
\hline Kangding Granite (KDG) & September 2009 & 20 & 2.6 & 1.8 & $\mathrm{~N} 39^{\circ} \mathrm{E}$ & [19] \\
\hline
\end{tabular}

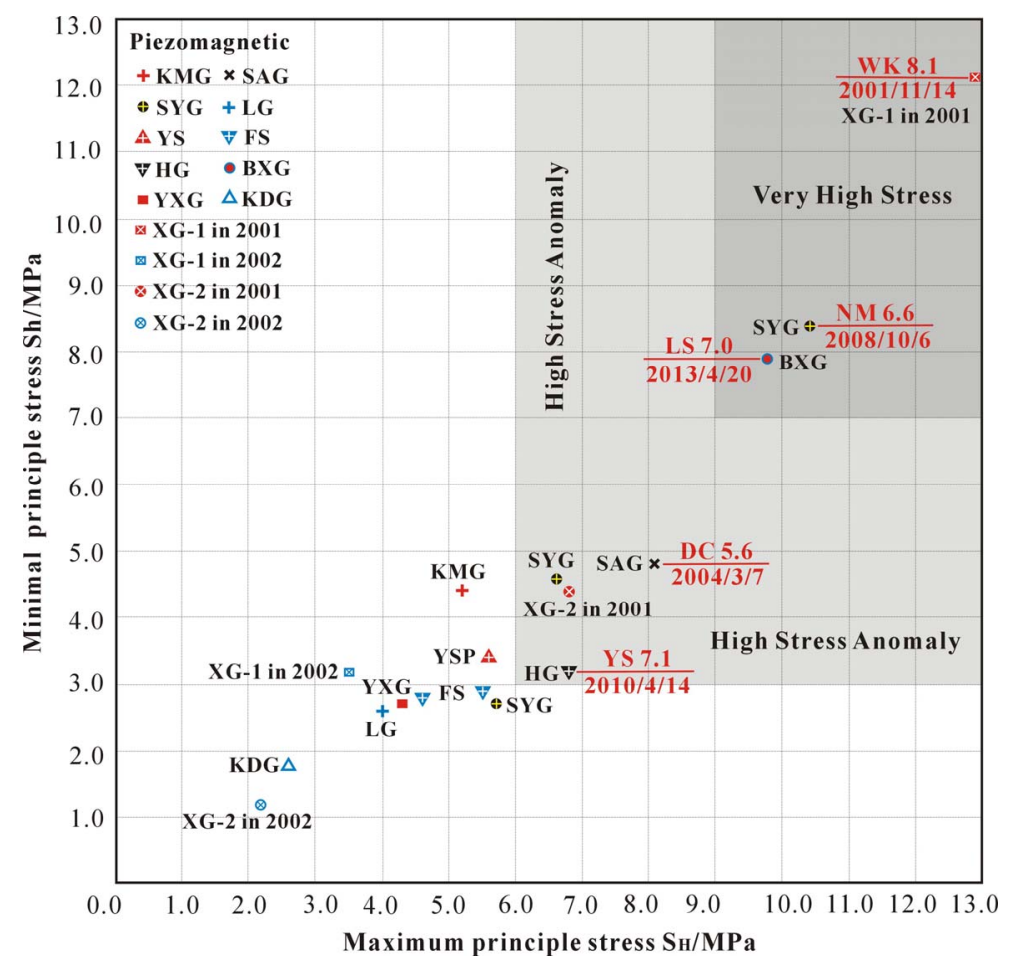

Figure 5. Diagram of piezomagnetic principle stress change in the Tibetan Plateau. Explanation: the SYG, KMG, FS and BXG et al. refer to the sites for piezomagnetic stress measurement, and the YS 7.1/2010/4/14 et al. refer to the related earthquakes occurred in recent years.

5). Maximum principle stress $\left(\mathrm{S}_{\mathrm{H}}\right)$ and minimal principle stress $\left(\mathrm{S}_{\mathrm{h}}\right)$ along the seismic fault increased to 6.8 - 12.9 $\mathrm{MPa}$ and 4.4 - 12.1 MPa, respectively, at a depth of 14 -
$18 \mathrm{~m}$, being 2.5 - 5.2 times higher than background stress 3 months before the Ms 8.1 West Kunlun Pass earthquake in the northern plateau, and decreased to normal 
stress state $\sim 8$ months after the earthquake (Table 2). The $\mathrm{S}_{\mathrm{H}}$ and $\mathrm{S}_{\mathrm{h}}$ in Yaoji granite on eastward thrust sheet increased to $14.44-25.53 \mathrm{MPa}$ at depths of 180.3 - 280.5 $\mathrm{m}$ before the Ms 8.0 Wenchuan earthquake, being $\sim 2$ times higher than background stress, and recovered to a normal stress state one year after the earthquake in Longmenshan Mountains at the eastern margin of the Tibetan Plateau (Figures 2 and 3). The $S_{H}$ and $S_{h}$ increased to 9.8 $\mathrm{MPa}$ and 7.9 $\mathrm{MPa}$, respectively, in BXG at depth of $18-22 \mathrm{~m}$, and $16 \mathrm{MPa}$ and $10 \mathrm{MPa}$, respectively, in LD at $150 \mathrm{~m}$ depth before the Ms 7.0 Lushan earthquake. The principle stress $\mathrm{S}_{\mathrm{H}}$ and $\mathrm{S}_{\mathrm{h}}$ increased to 2.2 - 4.2 times higher than background stress before the Ms 6.6 Nimu earthquake; stress in 3 orientations rapidly increased 0.10 - $0.12 \mathrm{MPa}$ within 45 days near seismic epicenter $\sim 8$ months before the Nimu earthquake in the southern Tibetan Plateau (Figure 4). A high stress anomaly also formed in Fenghuoshan (FS) and Hohxil (HG) along seismic faults before the Ms 7.1 Yushu earthquake occurred in April 2010.

Additional high stresses were also found in the Yanshiping sandstone (YSP) where the $\mathrm{S}_{\mathrm{H}}$ and $\mathrm{S}_{\mathrm{h}}$ were 5.6 $\mathrm{MPa}$ and 4.4 MPa, respectively, at a depth of $13 \mathrm{~m}$ in June 2003, and in the Kangma Granite (KMG) where the $\mathrm{S}_{\mathrm{H}}$ and $\mathrm{S}_{\mathrm{h}}$ were 5.2 $\mathrm{MPa}$ and 4.4 MPa, respectively, at a depth $13 \mathrm{~m}$ (Table 2). If the maximum stress $\mathrm{S}_{\mathrm{H}}$ continues to increase as much as $0.5-1.0 \mathrm{MPa}$ in the related areas, then the YSP and KMG will be plotted in the high stress anomaly in $\mathrm{S}_{\mathrm{H}}-\mathrm{S}_{\mathrm{h}}$ diagram (Figure 5). This high stress anomaly could be connected with some Ms 6.0 - 7.0 earthquake in the near future.

Significantly different types of fault zones show the stress increase even though they might be compressional or extensional structures. The West Kunlun Pass and Yushu earthquakes were due to strike-slip offset, the Wenchuan earthquake was due to oblique-slip thrust offset, the Lushan earthquake was due to thrust offset and the Nimu and Dongco earthquakes were due to normal fault offset. Thus, the fault type makes no obvious difference in the development of stress anomalies prior to an earthquake. Stress variations relative to rock mechanic changes [26] and tectonic divisions [6], local stress from non-tectonic processes as permafrost freezing [27] and ancient residual stress [10] might cause local stress anomalies, but these factors rarely lead to regional stress anomalies along active faults and result in regular stress changes before and after large earthquakes.

Apparently deep barriers acting as friction decrease slip rates or even stop slip along active faults and increase stress along the blocked segments of active faults, leading to high stress anomalies before large earthquakes (Figures 2, 3 and 5). This is a reflection of the strain build up near faults as proposed by Reid [2], but the resulting stress seems more restricted and the buildup is more rapid than what might be expected. These characteristics aid in using high stress anomalies in the upper crust surface as viable precursors for prediction of large earthquakes within continents, such as the Tibetan Plateau.

Other indices as Coulomb failure stress on faults $[28,29]$, tectonic stress and stress variations inferred from numerical modeling [12,30-32], and hydrochemistry anomalies [33] also have been suggested in forecasting earthquakes, but none are as sensitive to earthquakes as the in-situ measured stress in the Tibetan Plateau. The GPS measurements indicated low slip rates of active faults and low velocity of terrains in the Longmenshan Mountains [15], where the Wenchuan earthquake occurred, and no high velocity or strain anomalies were discovered by GPS measurements before the Ms 8.0 Wenchuan earthquake, the Ms 8.1 West Kunlun Pass earthquake, the Ms 6.6 Nimu earthquake, the Ms 7.1 Yushu earthquake and the Ms 7.0 Lushan earthquake in the Tibetan Plateau, implying that GPS measurements are not nearly as effective as in-situ stress measurements for earthquake prediction. Using stress to monitor earthquakes appears a practical approach for forecasting large continental earthquakes.

\section{ACKNOWLEDGEMENTS}

This research was supported by the Ministry of Land and Resources of China under grant No. 201211095 and China Geological Survey under grant Nos. 1212011120185 and 1212011221111 . Thanks to the Tibetan Bureau of Geology and Mineral Resources for their help in field drilling, and thanks to the expert who reviewed the manuscript.

\section{REFERENCES}

[1] Wu, Z.H., Barosh, Patrick, J., Zhang, Z.C. and Liao, H.J. (2012) Effects from the Wenchuan Earthquake and seismic hazard in the Longmenshan Mountains at the eastern margin of the Tibetan Plateau. Engineering Geology, 143144, 28-36. doi:10.1016/j.enggeo.2012.06. 006

[2] Reid, H.F. (1910) Mechanics of the earthquake, the California Earthquake of April 18, 1906. Report of the State Investigation Commission, Carnegie Institution of Washington, Washington DC.

[3] Li, S.-G. (1974) Earthquake geology. Science Press, Beijing.

[4] Li, F.Q. (2010) In-situ stress measurement is an important approach to realize earthquake prediction-Developing J.S. Lee's scientific ideas on earthquake prediction. In: Xue and Furen, Eds., Rock Stress and Earthquakes, CRC Press, Taylor and Francis Group, London, 757-759.

[5] Chen, Q.X. (1998) Analysis of rock mechanics and tectonic stress field. Geology Publishing House, Beijing.

[6] Yao, R., Yang, S.X., Lu, Y.Z., Cui, X.F., Chen, Q. and Mi, Q. (2010) Characteristics of tectonic stress in the east of Tibetan Plateau and its neighboring region inferred from 
in-situ stress measurements. In: Xue and Furen, Eds., Rock Stress and Earthquakes, CRC Press, Taylor and Francis Group, London, 687-693.

[7] Wu, M.L., Zhang, C.S., Liao, C.T., Ma, Y.S. and Ou, M.Y. (2005) The recent state of stress in the central Qinghai-Tibet Plateau according to in-situ stress measurements. Chinese Journal of Geophysics, 48, 327-332.

[8] Zoback, M.L. (1992) First and second order patterns of stress in the lithosphere: The world stress map project. Journal of Geophysical Research, 97, 11703-11728. doi:10.1029/92JB00132

[9] Heidbach, O., Tingay, M., Barth, A., Reinecker, J., Kurfe, D. and Miller, B. (2008) The release 2008 of the world stress map. www.world-stress-map.org

[10] Barosh, P.J. (1986) Neotectonic movement, earthquakes and stress state in the eastern United States. Tectonophysics, 132, 117-152. doi:10.1016/0040-1951(86)90029-6

[11] Xie, F.R., Zhang, H.Y. and Du, Y. (2010) The recent tectonic stress districts and strong earthquakes in China. In: Xue and Furen, Eds., Rock Stress and Earthquakes, CRC Press, Taylor and Francis Group, London, 35-40.

[12] Zhang, Y.-Q. and Xie, F.-R. (2010) Background stress state estimated from 2008 Wenchuan earthquake sequence. In: Xue and Furen, Eds., Rock Stress and Earthquakes, CRC Press, Taylor and Francis Group, London, 707-712.

[13] Molnar, P. and Tapponnier, P. (1978) Active tectonics of Tibet. Journal of Geophysical Research, 83, 5361-5375. doi:10.1029/JB083iB11p05361

[14] Tapponnier, P., Peltzer, A. Y., Le, Dain, Amijo, R. and Cobbold, P. (1982) Propagating extrusion tectonics in Asia: New insights from simple experiments with plasticine. Geology, 10, 611-616. doi:10.1130/0091-7613(1982)10<611:PETIAN>2.0.CO;2

[15] Zhang, P.Z., Shen, Z.K., Wang, M., Gan, W.J., Burgmann, R., Molnar, P., Wang Q., Niu, Z.J., Sun, J.Z., Wu, J.C., Sun, H.R. and You, X.Z. (2004) Continuous deformation of the Tibetan Plateau from global positioning system data. Geology, 32, 809-812. doi:10.1130/G20554.1

[16] China Seismological Bureau (2003) Album of the Ms 8.1 earthquake occurred in west of Kunlun Pass, China. Seismological Press, Beijing, 1-105.

[17] Wu, Z.H., Wu, Z.H., Hu, D.G., Wang, W., Zhang Z.C. and Lei, W.Z. (2005) Album of active faults and geological hazards along the Golmud-Lhasa Railway across the Tibetan Plateau. Seismological Press, Beijing, 1-150.

[18] Xu, X.W., Yu, G.H., Chen, G.H., Ran, Y.K., Li, C.X., Chen, Y.G. and Chang, C.P. (2009) Parameters of coseismic reverse- and oblique-slip surface ruptures of the 2008 Wenchuan earthquake, eastern Tibetan Plateau. Acta Geologica Sinica, 83, 673-684. doi:10.1111/j.1755-6724.2009.00091.x

[19] Wu, M.L., Zhang, Y.Q., Liao, C.T., Chen, Q., Ma, Y.S., Wu, J.S., Yan, J.F. and Ou, M.Y. (2009) Preliminary results of in-situ stress measurements along the Longmenshan fault zone after the Wenchuan Ms 8.0 earthquake. Acta Geologica Sinica, 83, 746-753. doi:10.1111/j.1755-6724.2009.00098.x

[20] Wu, Z.H., Dong, S.W., Barosh, P.J., Zhang Z.C. and Liao,
H.J. (2009) Dextral-slip thrust faulting and seismic events of the Ms 8.0 Wenchuan earthquake Longmenshan Mountains, eastern margin of the Tibetan Plateau. Acta Geologica Sinica, 83, 685-693. doi:10.1111/j.1755-6724.2009.00092.x

[21] Cao, Z.Q., Xie, P., Jin, H., Chen, Q. and Mao, J.Z. (2003) Variety characteristics of the crustal stress field near the Brahmaputra fault zone. Progress in Geophysics, 18, 167172.

[22] Mao, J.Z., Li, F.Q., Zhang, Z.G., Chen, Q., Ceng, J.Q. and Yang, X. (1999) Report on stress measurement by hydraulic fracturing in Yaoji reservoir dam. Institute of Crust Dynamics, China Seismological Bureau, Beijing.

[23] An, Q.M., Ding, L.F., Wang, H.Z. and Zhao, S.G. (2004) Research of property and activity of Longmenshan Mountain fault zone. Journal of Geodesy and Geodynamics, 24, 115-119.

[24] Liao, C.T., Zhang, C.S., Wu, M.L., Ma, Y.S. and Ou, M.Y. (2003) Stress change near the Kunlun Fault before and after the Ms 8.1 Kunlun Earthquake. Geophysical Research Letter, 30, 2027-2030. doi:10.1029/2003GL018106

[25] Zhang, C.S., Wu, M.L., Liao, C.T., Ma, Y.S. and Ou, M.Y. (2007) The result of current stress measurements and stress state analysis in the region of Yangbajain-Kangmar in Tibet. Chinese Journal of Geophysics, 50, 517-522.

[26] Hudson, J.A. and Feng, X.T. (2010) Variability of in situ rock stress. In: Xue and Furen, Eds., Rock Stress and Earthquakes, CRC Press, Taylor land Francis Group, London, 3-10.

[27] Wu, Z.H., Barosh, P.J., Wang, L.J., Hu, D.G. and Wang, W. (2008) Numerical modeling of stress and strain associated with bending of an oil pipeline by a migrating pingo in the permafrost region of the northern Tibetan Plateau. Engineering Geology, 96, 62-77. doi:10.1016/j.enggeo.2007.10.001

[28] Shan, B., Xiong, X., Zheng, Y. and Diao, F.Q. (2009) Stress changes on major faults caused by Mw 7.9 Wenchuan earthquake, May 12, 2008. Science in China Series D: Earth Sciences, 52, 593-601. doi:10.1007/s11430-009-0060-9

[29] Hori, T. and Kaneda, Y. (2004) Physical criterion to evaluate seismic activity associated with the seismic cycle of great intraplate earthquakes. Journal of Seismology, 8, 225-233. doi:10.1023/B:JOSE.0000021364.93301.2a

[30] Spudich, P., Guatteri, M., Otsuki, K. and Minagawa, J. (1998) Use of fault striations and dislocation models to infer tectonic stress during the 1995 Hyogo-Ken Nanbu (Kobe) earthquake. Bulletin of Seismological Society of America, 88, 413-427.

[31] Kato, N. and Hirasawa, T. (1999) The variation of stresses due to aseismic sliding and its effect on seismic activity. Pure and Applied Geophysics, 155, 425-442. doi:10.1007/s000240050273

[32] Tiampo, K.F., Bowman, D.D., Colella, H. and Rundle, J.B. (2008) The stress accumulation method and pattern informatics index: Complementary approaches to earthquake forecasting. Pure and Applied Geophysics, 165, 
693-709. doi:10.1007/s00024-008-0329-5

[33] Harmann, J. and Levy, K.J. (2006) The influence of seismotectonics on precursory changes in underground- water composition for the 1995 Kobe earthquake, Japan. Hydrogeology Journal, 4, 1307-1318.

doi:10.1007/s10040-006-0030-7 